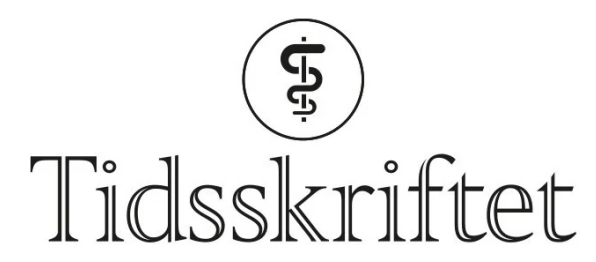

DEN NORSKE LEGEFORENING

\title{
Når sykehusinnleggelsen blir risikosport ...
}

GJESTESKRIBENT

TONE HOLTE

Frilansjournalist

Sjeldne diagnoser krever individuell tilnærming og helhetstenkning. Pasient og pårørende bør kunne stole på at informasjon om tilstanden blir innhentet og tatt hensyn til ved innleggelse i sykehus.

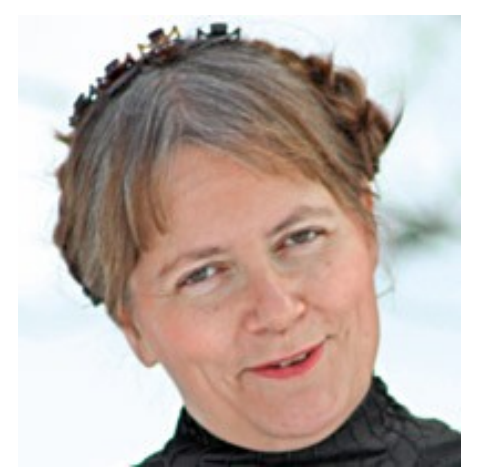

«En gang sendte jeg med en vitenskapelig artikkel før hun skulle opereres for å gjøre dem oppmerksomme på dette med narkosen. Jeg var med på sykehuset og forlangte å snakke med legen som skulle operere, og så viste det seg at noen hadde tatt vekk artikkelen og kastet den. Resultatet var at operasjonen måtte utsettes, for legen visste ikke at hun hadde dystrofia myotonika og han ville sette seg skikkelig inn i risikoene først.» Eksemplet er hentet fra SINTEF-rapporten Sjeldne funksjonshemninger i Norge. Brukeres erfaring med tjenesteapparatet.

Pasienten hadde den sjeldne nevromuskulære sykdommen dystrophia myotonica. Visse medikamenter kan ha ugunstig virkning på pust og hjertefunksjon. Narkose vil kunne medføre økt risiko for komplikasjoner, og anbefalingen er at man generelt skal være svært tilbakeholden med inngrep i narkose. Hvordan ville det gått uten en årvåken pårørende som sørget for at denne informasjonen kom frem til kirurgen?

«Den sjeldne erfaringen dreier seg om opplevelsen av å falle utenfor fagfolks kunnskapsunivers,» konkluderer forskerne bak rapporten. Dette er både strevsomt og truende. Situasjonen gjør den enkelte svært sårbar og svært avhengig av de stedene i Norge 
der man kan tilby kompetent hjelp. Kompetansesentrene spiller en nøkkelrolle ved at man der kan bistå sykehusene i å gi en best mulig behandling til «de sjeldne». Og ved sykehusene må man forstå nødvendigheten av å benytte seg av denne kompetansen.

En annen rapport - En vanskelig pasient? Sykehusene og pasienter med sjeldne tilstander - viser at dette er svært viktig. Denne NOVA-rapporten er basert på et begrenset antall intervjuer med personer som har en sjelden eller lavfrekvent diagnose samt leger ved sykehus og kompetansesentre. Pasientfortellingene viser at det ved sykehusene ofte er mangelfull kunnskap om hvilken betydning den sjeldne diagnosen kan ha for annen medisinsk behandling. Pasientene opplever at mange leger bagatelliserer dette. De opplever sjelden at behandlende lege tar kontakt med medisinsk ekspertise som har kunnskap om diagnosen selv om pasienten eller en pårørende ber om dette. De opplever at viktige opplysninger enten ikke er skrevet inn i journalen eller ikke er blitt lest. Pasienten må ofte selv informere og oppdatere de ulike avdelingene og spesialistene ved sykehuset. Dessuten erfarer de at de ikke blir hørt når de protesterer mot foreslåtte behandlingsprosedyrer. Følgen er feilbehandling eller behandling der de påføres unødige plager.

Et sykehusopphold betyr medisinsk behandling, men også at pasienten skal sove, spise og gå på toalettet. For noen er det avgjørende at de rette tekniske hjelpemidlene er på plass, for andre er for eksempel tolk helt nødvendig. De to rapportene viser at slikt heller ikke er noen selvfølge. NOVA-rapporten tegner et bilde av «de sjeldne» som grupper som ikke passer inn i de spesialiserte sykehusene. Dette fordi de har sykdommer og helsetilstander som gjør at ordinære prosedyrer ikke uten videre kan følges. I tillegg kan det være behov for koordinering av innsatsen fra flere avdelinger, noe som byr på utfordringer i dagens system.

Legene som er intervjuet i NOVA-rapporten, bekrefter i det store og hele pasientenes egne fortellinger. Alle ønsker pasientens beste. Spørsmålet blir da: Hvorfor i all verden skjer dette? Noen av legene erkjenner at de som fagperson muligens har for stor tiltro til egen kunnskap. Tidspress kan føre til raske avgjørelser. Rutinene for kunnskapsoverføring fungerer ikke alltid, og viktig informasjon går tapt. Spesialiseringen er en hindring for en helhetlig medisinsk forståelse, blant annet er det ofte ingen som har koordinerende og overordnet ansvar for pasienten. Rapporten trekker frem ordningen med pasientansvarlig lege som et tiltak som vil være spesielt nyttig for de «sjeldne pasientene». Det viser seg dessverre at ordningen er lite benyttet.

Må vi ha det sånn? Det er godt dokumentert at sjeldne diagnoser faktisk krever individuell tilnærming og helhetstenkning. Det er derfor avgjørende at sykehuspersonellet til enhver tid er oppdatert. Journalsystemer og rutiner i sykehusene må være tilrettelagt for dette. Dette er mulig å få til om det er et sterkt nok ønske om det. Én vei å gå er å bygge videre på den kompetansen som allerede finnes i enkelte medisinske miljøer i Norden. Hva om pasienten bar et identifikasjonskort med informasjon om hvor kompetanse på tilstanden finnes? Kompetansesentrene er til for å brukes!

Publisert: 12. august 2010. Tidsskr Nor Legeforen. DOI: 10.4045/tidsskr.09.1414

(C) Tidsskrift for Den norske legeforening 2023. Lastet ned fra tidsskriftet.no 26. april 2023. 